\title{
АДАПТАЦИЯ ПАНКРЕАТИЧЕСКОЙ СЕКРЕЦИИ И МЕТАБОЛИЗМА У ЖИВОТНЫХ С РАЗНЫМ ТИПОМ ПИЩЕВАРЕНИЯ ПРИ ЗАМЕНЕ БЕЛКОВОГО КОМПОНЕНТА РАЦИОНА*
}

\section{В.И. ФИСИНИН 1 , В.Г. ВЕРТИПРАХОВ ${ }^{1}$, Е.Л. ХАРИТОНОВ ${ }^{2}$, А.А. ГРОЗИНА 1}

Вопрос о способности поджелудочной железы адаптироваться к характеру питания остается дискуссионным. Из-за методических трудностей получения чистого панкреатического сока данные об изменении секреторной функции у сельскохозяйственных животных малочисленны и разноречивы (А.Д. Синещеков, 1965; П.П. Бердников, 1990; Ц.Ж. Батоев, 2001; A. Huguet с соавт., 2006; В.И. Фисинин с соавт., 2017; К. Liu с соавт., 2018), а влияние определенных ингредиентов в составе корма на панкреатическую секрецию до сих пор не было предметом изучения. В представленной работе мы сопоставили показатели внешнесекреторной функции поджелудочной железы при замещении одного из компонентов рациона, использовав для исследования животных с неодинаковым типом пищеварения аналогичные методы, что позволило выявить как особенности, так и общие закономерности происходящих приспособительных реакций. Нашей целью было изучение механизмов адаптации панкреатической секреции и метаболизма у животных с разным типом пищеварения при замене соевого жмыха (шрота) на подсолнечный. Исследования выполнялись на 18 курах-несушках (Gallus gallus L.) кросса Хайсекс белый (Hisex White) 10-12-месячного возраста (из них 3 - с хронической фистулой панкреатического протока по Ц.Ж. Батоеву, 2001) и 5-месячных поросятах (Sus scrofa domesticus L.) помеси датского ландраса и датского йоркшира с живой массой 45-55 кг (9 гол.: 3 - с канюлей панкреатического протока, 3 - с канюлей подвздошной кишки, 3 - интактные). Показано, что у кур наиболее выраженные изменения в ферментативной активности при замене в рационе соевого жмыха на подсолнечный наблюдаются по липазе: при использовании подсолнечного жмыха в базальный период (до кормления) этот показатель повышается на $37,7 \%$ (р < 0,05), в постпрандиальный период (на 90-й мин опыта) - на $46,6 \%(p<0,05)$, на 150 -й мин - на 93,7\%. В результате переваривание сырого жира усиливается при использовании подсолнечного жмыха на $3,5 \%(p<0,05)$ по сравнению с таковым для рациона, содержащим соевый жмых. В динамике протеаз у кур отмечается увеличение активности ферментов в постпрандиальный период при замене соевого жмыха на подсолнечный, однако при этом переваримость сырого протеина существенно не изменяется. У свиней при замене соевого шрота подсолнечным жмыхом поджелудочная железа, напротив, реагирует снижением протеолитической активности на $43,8 \%$ (p < 0,05). При этом переваримость сырого протеина не изменяется, что согласуется с наличием ингибитора трипсина в соевом шроте. Несмотря на близкие показатели валового количества панкреатического сока за опыт при использовании корма с разными белковыми ингредиентами, в динамике выделения секрета в постпрандиальную фазу у свиней отмечаются существенные различия как в сложнорефлекторный, так и в нейрогуморальный период регуляции панкреатической секреции. Наши эксперименты показали, что экзокринная функция поджелудочной железы у птицы характеризуется высокой активностью: у кур по сравнению со свиньями количество панкреатического сока на единицу живой массы больше в 2,2 раза, активность амилазы выше в 94 раза, протеаз - в 145 раз, липазы - в 17 раз. Индекс активности трипсина в плазме крови у кур значительно (в 7 раз) превышает показатель у свиней, что свидетельствует о более интенсивном обмене веществ. Следовательно, при замене компонентов рациона необходимо учитывать функциональные особенности адаптации панкреатической секреции у животных с разным типом пищеварения, поскольку секреторная функция поджелудочной железы и переваримость корма коррелируют, что, в свою очередь, влияет на продуктивность животных.

Ключевые слова: поджелудочная железа, экзокринная функция, куры, свиньи, активность пищеварительных ферментов крови.

Вопрос об адаптации поджелудочной железы к качеству питания у животных до настоящего времени дискутируется. Существует мнение о параллельных изменениях активности ферментов в соке поджелудочной железы. Согласно гипотезе параллельной секреции, активность ферментов

\footnotetext{
* Исследование выполнено при финансовой поддержке подпрограммы «Изучение механизмов адаптации системы пищеварения млекопитающих животных и птицы к рационам с различным ингредиентным составом кормов» в соответствии с Программой фундаментальных исследований РАН (постановление Президиума РАН № 132 от 05.07.2017).
}

1122 
поджелудочной железы изменяется в одних и тех же пропорциях, независимо от компонентов пищи (1). Такие результаты были получены на канюлированных собаках, постоянно теряющих панкреатический сок, у которых способность поджелудочной железы приспосабливать ферментативный состав секрета к характеру пищи в значительной степени нарушена (2). Подобный дисбаланс возникает при заболеваниях органов пищеварения, а также при избыточном поступлении питательных веществ, в частности жиров (2). Однако имеется большое количество экспериментальных данных, указывающих на способность поджелудочной железы изменять активность ферментов и сокоотделение в зависимости от состава потребляемой пищи (3-6), в том числе это описано у птиц (7-11). Доказательства приспособления пищеварительных желез к качеству пищи получены с помощью современных методов в процессе синтеза, транспорта и выделения зимогенных гранул на уровне как отдельных ацинарных клеток, так и ацинусов топографически разных участков железы (12-14). В настоящее время все больше внимания уделяется молекулярно-генетическим подходам в изучении секреторной функции поджелудочной железы (15), и хотя эти методы не нашли широкого распространения в изучении адаптации панкреаса к качеству питания, полученные немногочисленные результаты согласуются с биохимическими данными $(16,17)$. Особый интерес представляют эксперименты на животных с канюлей, которая позволяет отбирать образцы панкреатического сока in vivo в период опытов, а в остальное время направлять его в кишечник. Следует отметить, что из-за методических трудностей получения чистого панкреатического сока имеющиеся данные об адаптации секреторной функции сельскохозяйственных животных малочисленны и разноречивы $(18,19)$. В прошлом веке академиком И.П. Павловым был разработан метод исследования панкреатического сока у собак и получены экспериментальные данные по адаптации панкреатической секреции к хлебу, молоку, мясу, которые стали основой физиологии пищеварительной системы (3). Позднее на сельскохозяйственных животных изучалось приспособление панкреатической секреции к различным кормам и добавкам $(7-9,20)$, однако влияние определенных ингредиентов корма на панкреатическую секрецию не было предметом изучения.

В представленной работе впервые описаны количественные изменения секреторной функции поджелудочной железы при замещении одного из компонентов рациона. Кроме того, благодаря использованию аналогичных методов исследования панкреатической секреции (эксперименты на фистулированных особях), сопоставлены показатели у животных с неодинаковым типом пищеварения, что позволило выявить у них как особенности, так и общие закономерности приспособительных реакций панкреаса.

Нашей целью было изучение механизмов адаптации системы пищеварения млекопитающих животных и птицы в сравнительном аспекте к рационам с различными белковыми ингредиентами корма.

Методика. Объектами исследования были куры (Gallus gallus L.) породы леггорн яичного кросса Хайсекс белый (Hisex White) в возрасте 1012 мес с хроническими фистулами панкреатического протока (3 гол.), интактные куры (15 гол.), поросята (Sus scrofa domesticus L.) помеси датского ландраса и датского йоркшира в возрасте 5 мес с живой массой 45-55 кг (9 гол.: 3 - с канюлей панкреатического протока, 3 - с канюлей подвздошной кишки, 3 - интактные).

Для получения от птицы «чистого» панкреатического сока в хрони- 
ческом эксперименте (7) выполняли хирургическую операцию, суть которой сводилась к созданию изолированного отрезка 12-перстной кишки и трансплантации в него главного панкреатического протока с вживлением двух Г-образных фистул и образованием внешнего анастомоза, позволяющего при необходимости возвращать панкреатический сок в 12-перстную кишку. Поросят оперировали по методу И.З. Ткачева (21). Из 12-перстной кишки выкраивали отрезок длиной 4-5 см, в который впадает панкреатический проток, вживляли У-образную канюлю (в изолированный отрезок кишки и в основную кишку), позволяющую возвращать панкреатический сок в 12-перстную кишку в период вне опытов.

Физиологические опыты на птице выполняли по методике, разработанной нами ранее (8). Использовали корм ПК-1 (ФНЦ «ВНИТИП» РАН, Россия) с разными белковыми ингредиентами. На каждой птице выполняли не менее 3 опытов по изучению пищеварения в каждый учетный период. Физиологические опыты на поросятах начинали утром в состоянии животных натощак после 14-часового голодания. Поросят помещали в специальный станок, в котором они находились в течение 3,5 ч. Для сбора панкреатического сока к фистуле через специальный резиновый переходник прикрепляли микропробирку. В первые 30 мин собирали сок после голодания, затем поросятам давали 500 г (1/3 от суточной нормы) комбикорма (СК-4, ВНИИФБиП, Россия) («Нормы и рационы кормления сельскохозяйственных животных. Справочное пособие» М., 2003) и продолжали собирать секрет через каждые 30 мин в течение 180 мин.

Биохимические исследования активности ферментов панкреатического сока выполняли следующими методами: определение амилазы - по Smith-Roe в модификации для определения высокой активности фермента (7), протеаз - по гидролизу очищенного казеина по Гаммерстену с колориметрическим контролем (КФК-3, «Загорский отпико-механический завод», Россия, $\lambda=450$ нм) (7), липазы - на биохимических анализаторах Sinnowa BS3000P («SINNOWA Medical Science \& Technology Co., Ltd», Китай) и Screen Master LIHD113 («Hospitex Diagnostics S.r.L.», Италия) с набором ветеринарных диагностических реагентов («ДИАКОН-ВЕТ», Россия) для определения концентрации липазы в крови животных.

Кровь для исследования у кур получали из подкрыльцовой вены, у свиней - из хвостовой вены до кормления. В пробирки добавляли свежеприготовленный раствор цитрата натрия, кровь центрифугировали 5 мин при 5000 об/мин, полученную плазму исследовали на проточном биохимическом полуавтоматическом анализаторе Sinnowa BS3000P («SINNOWA Medical Science \& Technology Co., Ltd», Китай) с использованием биохимических наборов («ДИАКОН-ВЕТ», Россия). Активность амилазы и липазы исследовали на приборе Chem well 2900 (Т) («Awareness Technology, Inc.», США) с использованием соответствующих наборов реагентов («Нuman $\mathrm{GmbH»,} \mathrm{Германия).} \mathrm{Активность} \mathrm{трипсина} \mathrm{оценивали} \mathrm{на} \mathrm{полуавтома-}$ тическом биохимическом анализаторе Sinnowa BS-3000P («SINNOWA Medical Science \& Technology Co., Ltd», Китай) (22).

Балансовые опыты по изучению переваримости питательных веществ рациона выполняли общепринятыми методами («Методика проведения научных и производственных исследований по кормлению сельскохозяйственной птицы. Молекулярно-генетические методы определения микрофлоры кишечника». Сергиев Посад, 2013).

Статистический анализ выполняли методом ANOVA (программный пакет Statistica 10.0, «StatSoft, Inc.» США; Microsoft Excel). Для показателей 
активности ферментов рассчитывали средние $(M)$ и стандартные ошибки средних $( \pm \mathrm{SEM})$, достоверность различий определяли по $t$-критерию Стьюдента, считая их статистически значимыми при $\mathrm{p}<0,05$.

Результаты. Этапы эксперимента описывает таблица 1.

1. Схема опыта по оценке эффектов замещения белкового компонента рационов (соевый жмых/шрот $\rightarrow$ подсолнечный жмых) у животных с разным типом пищеварения

\begin{tabular}{|c|c|c|}
\hline Этап исследования & Группа (период) & Особенности питания \\
\hline \multicolumn{3}{|c|}{ К у ры-не с ушк и (Gallus gallus L.) к р ос с а X ай с е к с бе лы й } \\
\hline Изучение секреторной функ- & Контрольная & Основной рацион (ОР) с соевым жмыхом (19,8 \%) \\
\hline ции поджелудочной железы & Опытная & ОР с подсолнечным жмыхом $(21,0 \%)$ \\
\hline Изучение переваримости & Контрольная & ОР с соевым жмыхом $(19,8$ \%) \\
\hline питательных веществ корма & Опытная & ОР с подсолнечным жмыхом (21,0 \%) \\
\hline Определение биохимических & Контрольная & ОР с соевым жмыхом $(19,8 \%)$ \\
\hline показателей крови & Опытная & ОР с подсолнечным жмыхом (21,0%) \\
\hline \multicolumn{3}{|c|}{$\begin{array}{c}\text { Порося та (Sus scrofa domesticus L.) по м ес и датского ландр ас а } \\
\text { и датского йоркшира }\end{array}$} \\
\hline Изучение секреторной функ- & Контрольная & ОР с соевым шротом $(18,5 \%)$ \\
\hline ции поджелудочной железы & Опытная & ОР с подсолнечным жмыхом (22,5 \%) \\
\hline Изучение переваримости & Контрольная & ОР с соевым шротом $(18,5$ \%) \\
\hline питательных веществ корма & Опытная & ОР с подсолнечным жмыхом (22,5 \%) \\
\hline Определение биохимических & Контрольная & ОР с соевым шротом $(18,5 \%)$ \\
\hline показателей крови & Опытная & ОР с подсолнечным жмыхом (22,5%) \\
\hline
\end{tabular}

Составы и характеристики использованных основных рационов приведены в таблицах 2 и 3.

\section{2. Состав (\%) и показатели качества рационов для кур-несушек (Gallus gallus L.) кросса Хайсекс белый}

\begin{tabular}{l|c|c}
\hline \multirow{2}{*}{$\begin{array}{l}\text { Ингредиент, } \\
\text { показатель }\end{array}$} & \multicolumn{2}{|c}{ Комбикорма } \\
\cline { 2 - 3 } & $\begin{array}{c}\text { контроль } \\
\text { (корм 1) }\end{array}$ & $\begin{array}{c}\text { опыт } \\
\text { (корм 2) }\end{array}$ \\
\hline Пшеница & 58,225 & 55,781 \\
Жмых подсолнечный & 5,000 & 21,026 \\
Жмых соевый & 19,784 & 8,912 \\
Известняк (36 \%) & 9,137 & 9,045 \\
Масло соевое & 1,936 & 3,026 \\
Отруби пшеничные & 3,847 & Отсутствует \\
Монокальцийфосфат & 1,149 & 1,233 \\
Соль поваренная & 0,250 & 0,250 \\
Лизин (98 \%) & 0,073 & 0,214 \\
Сульфат натрия & 0,205 & 0,182 \\
Метионин кормовой (98 \%) & 0,214 & 0,151 \\
Премикс & 0,180 & 0,180 \\
В 100 г комбикорма: & & \\
обменная энергия, ккал & 270,00 & 270,00 \\
сырая клетчатка, г & 4,89 & 5,92 \\
сырой протеин, г & 16,70 & 17,20 \\
сырой жир, г & 6,72 & 8,12 \\
Лизин, г & 0,73 & 0,80 \\
метионин, г & 0,44 & 0,45 \\
кальций, г & 4,78 & 4,61 \\
фосфор общий, г & 0,89 & 0,90 \\
\hline
\end{tabular}

В опыте на курах-несушках комбикорма готовили таким образом, чтобы в корме 1 преобладал жмых соевый, а в корме 2 - жмых подсолнечный. Анализ показал, что корм 2 содержал больше сырого жира (на 1,4 \%) и клетчатки (на 1,0\%), чем корм 1. При исследовании секреторной функции поджелудочной железы кур (рис. 1) мы выявили увеличение липоли-

\section{3. Состав (\%) и показатели качества рационов для помесных поросят (Sus scrofa domesticus L.)}

\begin{tabular}{|c|c|c|}
\hline \multirow{2}{*}{$\begin{array}{l}\text { Ингредиент, } \\
\text { показатель }\end{array}$} & \multicolumn{2}{|c|}{ Комбикорм } \\
\hline & $\begin{array}{l}\text { контроль } \\
\text { (корм 3) }\end{array}$ & $\begin{array}{l}\text { опыт } \\
\text { (корм 4) }\end{array}$ \\
\hline Пшеница & 50 & 47,4 \\
\hline Ячмень & 11,84 & 11,2 \\
\hline Отруби пшеничные & 15 & 14,2 \\
\hline Шрот соевый СП (42 \%) & 18,55 & Отсутствует \\
\hline Жмых подсолнечный & Отсутствует & 22,5 \\
\hline Масло подсолнечное & 1,45 & 1,0 \\
\hline Мел & 1,13 & 1,0 \\
\hline Трикальцийфосфат & 0,79 & 0,7 \\
\hline Соль поваренная & 0,24 & 0,24 \\
\hline Лизин & Отсутствует & 0,22 \\
\hline Треонин & Отсутствует & 0,11 \\
\hline Премикс КС-4-1 & 1 & 1,0 \\
\hline Итого & 100,0 & 100,0 \\
\hline \multicolumn{3}{|c|}{$\begin{array}{l}\text { В } 1 \text { кг комбикорма содержится: } \\
\text { энергетические кормовые }\end{array}$} \\
\hline единицы (ЭКЕ) & 1,28 & 1,28 \\
\hline обменная энергия, МДж, & 12,8 & 12,8 \\
\hline чистая энергия, МДж & 9,5 & 9,5 \\
\hline сухое вещество, г & 911,6 & 914,5 \\
\hline сырой протеин, г & 170,5 & 170,0 \\
\hline сырой жир, г & 34,8 & 44,1 \\
\hline линолевая кислота $\mathrm{C}_{18: 2} \%$ & 1,78 & 1,78 \\
\hline$\alpha$-линоленовая кислота, \% & 0,19 & 0,19 \\
\hline сырая клетчатка, г & 50,4 & 99,0 \\
\hline сырая зола, г & 51,8 & 65,1 \\
\hline $\begin{array}{l}\text { безазотистые экстрактив- } \\
\text { ные вешества (БЭВ), г }\end{array}$ & 638 & 683 \\
\hline лизин, Г & 7,8 & 7,8 \\
\hline метионин + цистин, г & 5,60 & 6,22 \\
\hline треонин, г & 5,9 & 5,9 \\
\hline кальций, г & 7,53 & 7,50 \\
\hline фосфор общий, г & 6,11 & 6,08 \\
\hline
\end{tabular}


тической активности на $33,8 \%$ (р < 0,05) при замене корма 1 на корм 2 , что, по-видимому, обусловлено качеством жира в подсолнечном жмыхе (23), а также повышением количества сырого жира в опыте относительно контроля. Активность протеаз возрастала на $28,1 \%(\mathrm{p} \geq 0,05)$ в результате изменения качества протеина и незначительного увеличения доли сырого протеина в корме (на 0,5 \%), а также содержания аминокислот, по которым в сумме показатель превышал таковой в контроле на 0,33 \%. Из этих результатов следует, что секреторная функция поджелудочной железы четко адаптируется к качеству потребляемого корма.

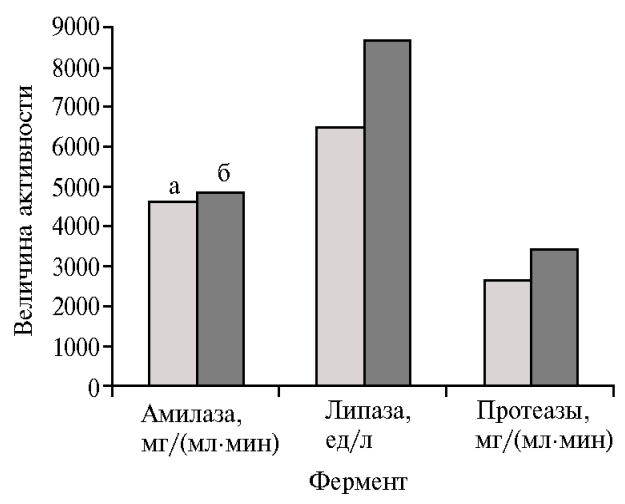

Рис. 1. Активность панкреатических ферментов при использовании в рационе кур-несушек (Gallus gallus L.) кросса Хайсекс белый разных белковых ингредиентов: а - корм 1 , б - корм $2(n=20$, лабораторный опыт на фистулированной птице; состав рационов см. в таблице 2, значения активности протеаз увеличены в 10 раз).

Для понимания механизмов приспособления продукции панкреатических ферментов к изменяющемуся составу рациона мы изучили динамику секреторной функции поджелудочной железы кур (рис. 2).
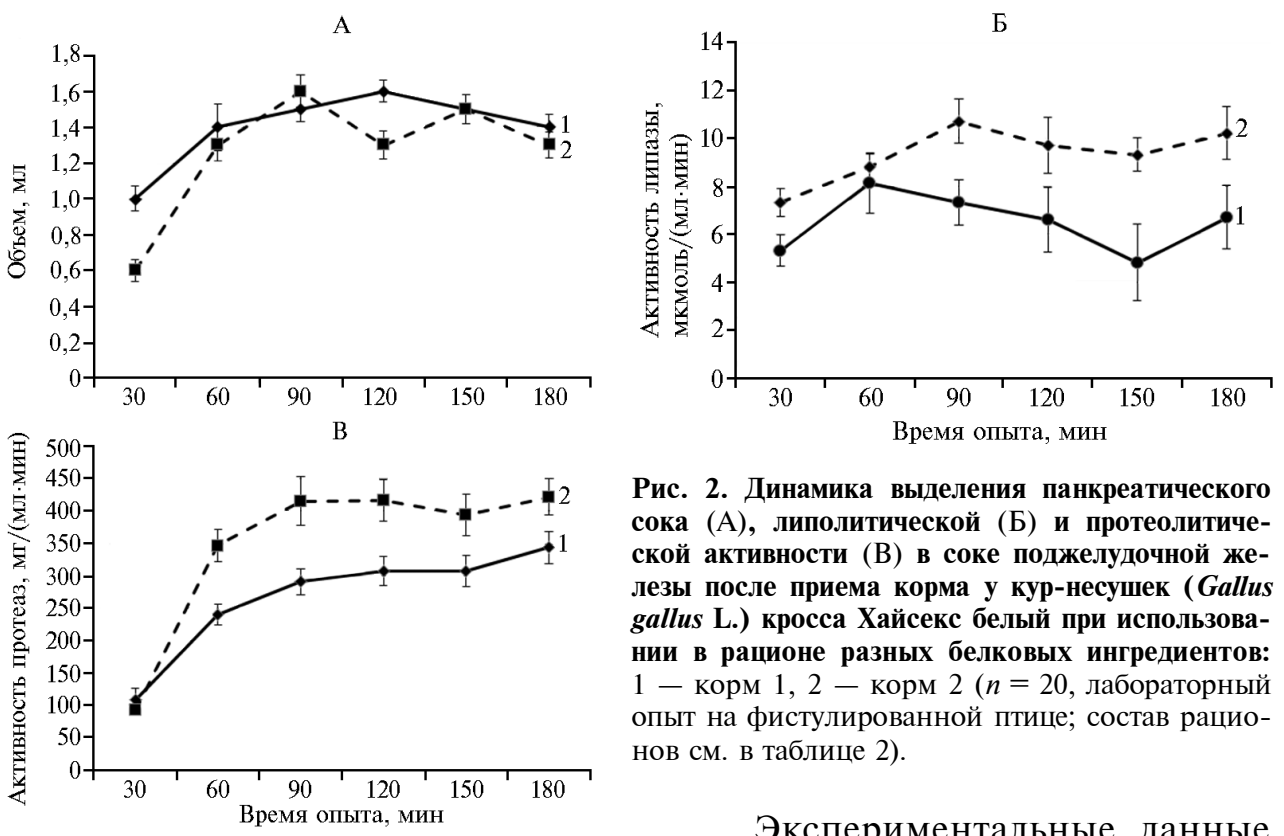

Рис. 2. Динамика выделения панкреатического сока (А), липолитической (Б) и протеолитической активности (В) в соке поджелудочной железы после приема корма у кур-несушек (Gallus gallus L.) кросса Хайсекс белый при использовании в рационе разных белковых ингредиентов: 1 - корм 1,2 - корм $2(n=20$, лабораторный опыт на фистулированной птице; состав рационов см. в таблице 2).

Экспериментальные данные свидетельствуют о том, что в динамике выделения панкреатического сока после приема корма наблюдаются различия при использовании в рационе кур разных комбикормов в 1-й и 4-й временной интервал опыта (см. рис. 2, А), что связано со сложнорефлекторной и нейрохимическими фазами регуляции внешнесекреторной функции поджелудочной железы $(7,8)$.

Наиболее выраженно изменяется ферментативная активность липазы (см. рис 2, Б): увеличение составило в 1-й период (до кормления) 37,7 \% $(\mathrm{p}<0,05)$ на 90-й мин $-46,6 \%(\mathrm{p}<0,05)$ при использовании подсолнечного жмыха, на 150-й мин - 93,7 \%. Разница базальной активности фер- 
ментов при использовании разных белковых добавок указывает на долговременную адаптацию к корму 2, который вызывает усиление липолитической активности. Основное различие в динамике состоит в том, что интенсивный рост активности липазы при наличии в корме подсолнечного жмыха продолжался до 90-й мин опыта, и далее ее величина сохранялась до конца эксперимента.

Динамика протеолитической активности в панкреатическом соке кур при замене в рационе соевого жмыха на подсолнечный (см. рис. 2, В) не имела принципиальных различий, но при этом кривая активности фермента при использовании в рационе кур подсолнечного жмыха располагается выше. Если до кормления показатели активности существенно не различались, то на 60-й, 90-й и 120-й мин опыта активность протеаз при введении в рацион подсолнечного жмыха становилась достоверно выше показателей, характерных для рациона с соевым жмыхом. Первые 30-60 мин постпрандиального периода соответствуют сложнорефлекторной фазе регуляции панкреатической секреции, которая определяется как условными, так и безусловными рефлексами (благодаря наличию вкусовых рецепторов в ротовой полости кур) (24-26), а с 90-й мин - гормональными факторами, также влияющими на секреторную функцию поджелудочной железы (27).

С секреторной функцией поджелудочной железы кур связана переваримость питательных веществ корма (табл. 4).

4. Переваримость и использование питательных веществ корма у кур-несушек (Gallus gallus L.) кросса Хайсекс белый при разных белковых ингредиентах в рационе ( $M \pm \mathrm{SEM}, n=10$, лабораторный опыт на интактной птице)

\begin{tabular}{|c|c|c|c|c|c|c|c|c|c|}
\hline \multirow[b]{2}{*}{ Рацион } & \multicolumn{4}{|c|}{ Переваримость, \% } & \multicolumn{2}{|c|}{ Доступность, \% } & \multicolumn{3}{|c|}{ Использование, \% } \\
\hline & протеина & \begin{tabular}{|l|} 
сухого \\
вещества
\end{tabular} & жира & клетчатки & $\mathrm{Ca}$ & $\mathrm{P}$ & азота & лизина & $\begin{array}{l}\text { метио- } \\
\text { нина }\end{array}$ \\
\hline Корм 1 & $88,3 \pm 0,43$ & $73,0 \pm 0,73$ & $90,1 \pm 0,67$ & $24,1 \pm 2,42$ & $62,8 \pm 2,90$ & $27,3 \pm 3,51$ & $55,5 \pm 1,94$ & $90,0 \pm 1,16$ & $95,1 \pm 0,32$ \\
\hline Корм 2 & $86,9 \pm 0,46$ & $71,5 \pm 0,86$ & $93,6 \pm 0,58 *$ & $11,8 \pm 2,74^{*}$ & $64,2 \pm 2,82$ & $32,3 \pm 4,06$ & $51,9 \pm 1,87$ & $90,9 \pm 0,25$ & $93,7 \pm 0,28$ \\
\hline
\end{tabular}

Анализ переваримости и доступности питательных веществ кормов показывает, что замена соевого жмыха подсолнечным ухудшила переваримость клетчатки на $12,3 \%$ ( $<<0,05)$, сухого вешества корма - на $1,5 \%$, протеина - на $1,4 \%$, метионина - на $1,4 \%$. В корме 2 сырой жир переваривался на $3,5 \%(\mathrm{p}<0,05)$ лучше, чем в корме 1 , что согласуется с липолитической активностью сока поджелудочной железы (см. рис. 2).

5. Биохимические показатели крови у кур-несушек (Gallus gallus L.) кросса Хайсекс белый при разных белковых ингредиентах в рационе $(M \pm \mathrm{SEM}, n=15$, лабораторный опыт на интактной птице)

\begin{tabular}{|c|c|c|c|}
\hline Показатель & Контроль (корм 1) & Опыт (корм 2) & К контролю, \% \\
\hline Трипсин, ед/л & $154 \pm 16,8$ & $105 \pm 10,8^{*}$ & $-31,8$ \\
\hline Амилаза, ед/л & $166 \pm 9,3$ & $202 \pm 27,8$ & $+21,7$ \\
\hline Липаза, ед/л & $38 \pm 2,5$ & $32 \pm 2,2$ & $-15,8$ \\
\hline Общий белок, г/л & $23,5 \pm 1,40$ & $38,6 \pm 3,40^{*}$ & $+64,2$ \\
\hline Мочевая кислота, мкмоль/л & $95 \pm 10,3$ & $109 \pm 14,9$ & $+14,7$ \\
\hline Глюкоза, ммоль/л & $2,8 \pm 0,58$ & $4,1 \pm 0,91$ & $+46,4$ \\
\hline Щелочная фосфатаза, ед/л & $853 \pm 85,0$ & $503 \pm 81,1^{*}$ & $-41,0$ \\
\hline Холестерин, ммоль/л & $2,6 \pm 0,70$ & $3,9 \pm 0,90$ & $+50,0$ \\
\hline Триглицериды, ммоль/л & $5,6 \pm 1,63$ & $8,7 \pm 2,76$ & $+55,3$ \\
\hline $\begin{array}{l}\text { П р и м е ч а н и е. Состав р } \\
\text { * Различие с контролем ста }\end{array}$ & $\begin{array}{l}\text { в см. в таблице } 2 . \\
\text { ски значимо при р }\end{array}$ & & \\
\hline
\end{tabular}

Биохимическое исследование крови кур-несушек (табл. 5) выявило существенные изменения в показателях, связанных с белковым обменом. 
Активность трипсина в опытный период снижалась на $31,8 \%$ (p < 0,05). В случае контрольного рацион с соевым жмыхом активность трипсина в крови была высокой. Переход птицы на рацион, аналогичный по уровню протеина, но с иным ингредиентным составов (замена соевого жмыха подсолнечным жмыхом), приводила к снижению активности трипсина в крови, по-видимому, из-за увеличения активности общих протеаз в кишечнике (28). Возможно, это обусловлено наличием в подсолнечном жмыхе хлорогеновой кислоты, ингибирующей трипсин и липазу (23). Содержание общего белка в контроле было ниже оптимального, что, по-видимому, связано с дефицитом полноценных белков и лимитирующих аминокислот в рационе. Не случайно, что в опыте использование комбикорма вызывало повышение (в пределах погрешности) показателя по мочевой кислоте и увеличение содержания общего белка в крови на 64,2 \% (p < 0,05), что соответствует его нормальному физиологическому значению для кур-несушек. Снижение активности щелочной фосфатазы на 41,0 \% (p < 0,05) свидетельствует об изменении функции печени, которая вырабатывает этот фермент, гидролизующий фосфорные связи.

В рационах подопытных поросят используемые комбикорма неодинаковы по содержанию сырого жира и клетчатки: в корме 4 по сравнению с кормом 3 содержание этих компонентов было выше соответственно на 9,3 и 21,1 \%; по количеству сырого протеина рационы не различались. Состав лимитирующих аминокислот и их содержание также практически не различались благодаря корректировке с использованием разного количества синтетических аминокислот. Превышение по метионину и цистину в корме 4 (даже без внесения синтетического метионина в комбикорм) было обусловлено их повышенным содержанием в подсолнечном жмыхе.

6. Секреторная функция поджелудочной железы у 5-месячных поросят (Sus scrofa domesticus L.) помеси датского ландраса и датского йоркшира при использовании в рационе разных по составу кормов ( $M \pm \mathrm{SEM}, n=3$, лабораторный опыт на фистулированных животных)

\begin{tabular}{|c|c|c|}
\hline Показатель & Контроль (корм 3) & Опыт (корм 4) \\
\hline Количество панкреатического сока за опыт, мл & $139,5 \pm 1,50$ & $134,9 \pm 7,16$ \\
\hline \multicolumn{3}{|l|}{ Активность ферментов в 1 мл сока: } \\
\hline амилаза, мг/(мл · мин) & $1564 \pm 267,0$ & $1800 \pm 92$ \\
\hline липаза, мкмоль/(мл · мин) & $14,8 \pm 1,01$ & $15,1 \pm 1,16$ \\
\hline протеазы, мг/(мл · мин) & $88,1 \pm 9,92$ & $49,6 \pm 6,04^{*}$ \\
\hline
\end{tabular}

Результаты исследований секреторной функции поджелудочной железы поросят (табл. 6) показывают, что при замене соевого белка на подсолнечный активность липазы не изменялась, хотя содержание жира в этом комбикорме было на 9,3 \% выше по сравнению с контрольным рационом. Возможно, причина связана с наличием хлорогеновой кислоты в подсолнечном жмыхе, которая служит ингибитором трипсина и липазы. Мы не обнаружили достоверных различий в активности амилазы. Количество протеаз снижалось на 43,7 \% в опытный период при одинаковом содержании протеина и аминокислот в комбикормах 3 и 4. Следовательно, у поросят (как и у кур) секреторная функция поджелудочной железы адаптируется к качеству корма. Анализируя механизмы адаптации панкреаса к новому корму, мы сравнили динамику выделения панкреатического сока и активности ферментов после кормления животных (рис. 3, А, Б).

Полученные данные свидетельствуют (см. рис. 3, А), что у поросят в первые 30 мин после приема корма выделение панкреатического сока уси- 
ливалось в 2,0 и 1,3 раза при использовании в рационе соответственно соевого или подсолнечного компонента. В дальнейшем к 90-й мин опыта в варианте с соевым шротом количество панкреатического сока снижалось до исходного значения, с подсолнечным жмыхом - продолжало возрастать до 90-й мин опыта и становилось в 2 раза выше по сравнению с предшествующим периодом. Со 120-й до 210-й мин опыта наблюдалось увеличение секреции в первый период, во второй период (при введении в рацион подсолнечного жмыха) существенных изменений в количестве секрета не отмечали. Следовательно, несмотря на близкие показатели валового количества панкреатического сока за опыт, в вариантах с разными белковыми ингредиентами корма динамика выделения секрета после приема корма существенно различалась как в сложнорефлекторную, так и в нейрогуморальную фазу регуляции панкреатической функции.

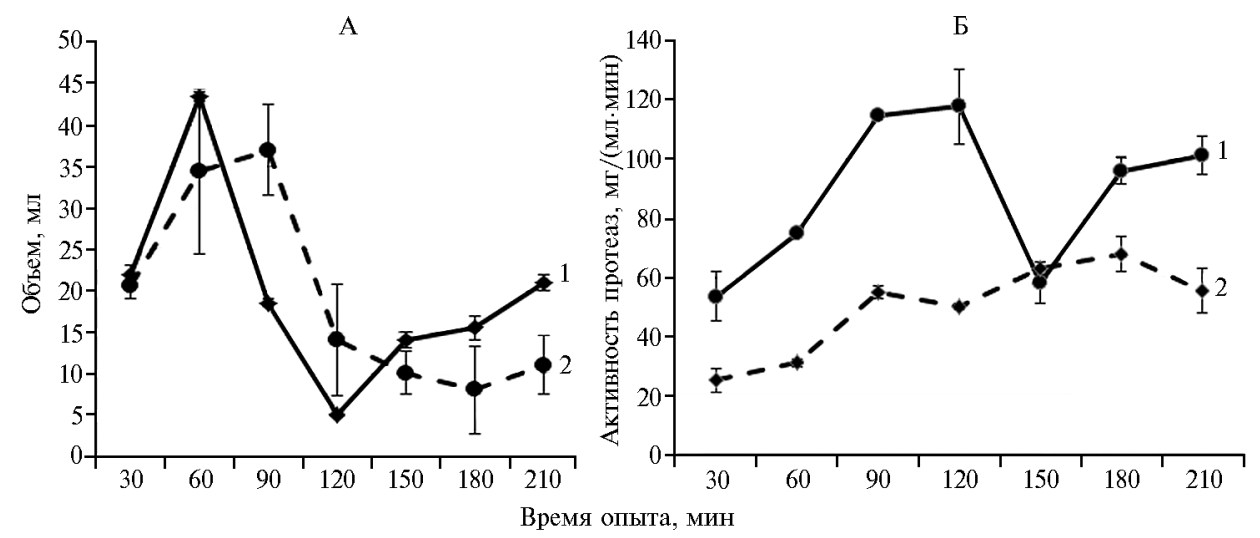

Рис. 3. Динамика выделения панкреатического сока (А) и протеолитической активности (Б) в соке поджелудочной железы после приема корма у 5-месячных поросят (Sus scrofa domesticus L.) помеси датского ландраса и датского йоркшира при использовании в рационе разных по составу кормов: $1-$ корм $3,2-$ корм 4 ( $n=20$, лабораторный опыт на фистулированных животных; состав рационов см. в таблице 3 ).

Поскольку в активности протеаз мы отмечали значительные изменения, была проанализирована динамика этого показателя в постпрандиальный период при разных источниках белка в корме поросят (см. рис. 3, Б). Протеолитическая активность в контроле (корм 3) усиливалась в постпрандиальную фазу пищеварения до 120-й мин опыта, затем следовал спад и новый подъем, характерный для нейрохимической фазы регуляции панкреатической секреции. При использовании в рационе поросят подсолнечного жмыха динамика активности протеаз характеризовалась увеличением в течение 60 мин после кормления (как и в контроле) в 2,2 раза, но поскольку базальный уровень активности был в 2 раза ниже, то и величина этого показателя в постпрандиальный период существенно отличалась во всех точках кривой, кроме 150-й мин (пересечение графиков). Следовательно, у поросят при замене в рационе одного белкового компонента на другой поджелудочная железа реагирует изменением преимущественно протеолитической активности, что свидетельствует об адаптации секреторной функции панкреаса к качеству корма.

У поросят после замены белкового компонента корма существенных изменений в динамике активности амилазы и липазы не наблюдали.

Таким образом, замена в рационе поросят соевого шрота на подсолнечный жмых отражается на динамике выделения панкреатического сока и активности протеаз в постпрандиальный период пищеварения, что указывает на адаптацию поджелудочной железы к индивидуальным ком- 
понентам корма при одинаковом содержании сырого протеина в комбикормах. Исследование висцеральных органов у поросят-отъемышей, получавших обычный и низкоолигосахаридный соевый шрот, не выявило различий (29). В то же время молекулярно-генетические методы in vitro позволяют заключить, что содержания жиров и углеводов в рационе свиней существенно влияет на экспрессию генов (30). Поэтому использование канюлированных животных для изучения адаптации панкреатической секреции имеет перспективу.

При замене соевого шрота на подсолнечный жмых достоверно не изменялась ни видимая, ни илеальная переваримость протеина (табл. 7), хотя при оценке доступности питательных веществ рациона илеальный метод считается наиболее объективным (31). Даже при большем содержании клетчатки и жира во втором рационе (опыт) отмечалось достоверное повышение их переваримости - соответственно на 11,7 и 28,7 \% $(\mathrm{p}<0,05)$. При этом хуже переваривалась зола и безазотистые экстрактивные вещества.

7. Переваримость и использование питательных веществ корма у 5-месячных поросят (Sus scrofa domesticus L.) помеси датского ландраса и датского йоркшшра при использовании в их рационе разных по составу кормов $(M \pm \mathrm{SEM}, n=10)$

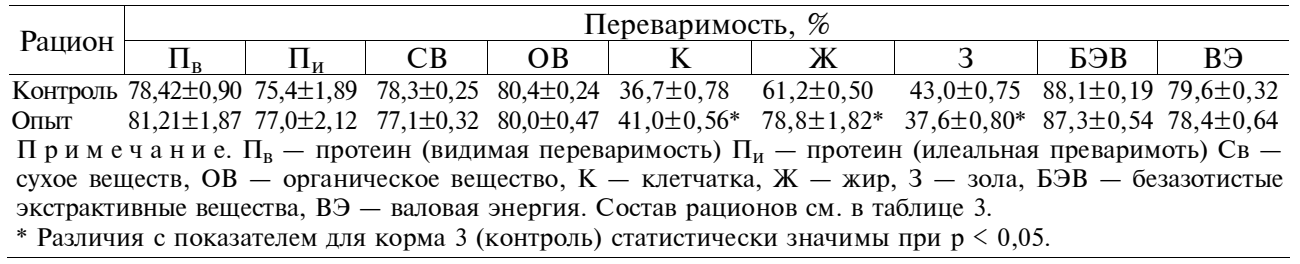

8. Биохимические показатели крови у 5-месячных поросят (Sus scrofa domesticus L.) помеси датского ландраса и датского йоркшира при использовании в их рационе разных по составу кормов $(M \pm \mathrm{SEM}, n=10)$

\begin{tabular}{lcc}
\hline \multicolumn{1}{c|}{ Показатель } & Контроль (корм 3) & Опыт (корм 4) \\
\hline Трипсин, ед/л & $690 \pm 56,0$ & $620 \pm 34,1$ \\
Амилаза, ед/л & $179,5 \pm 83,9$ & $141,7 \pm 32,7$ \\
Липаза, ед/л & $51,0 \pm 12,75$ & $76,5 \pm 22,08$ \\
Общий белок, г/л & $57,03 \pm 2,59$ & $62,2 \pm 2,24$ \\
Мочевина, ммоль/л & $4,3 \pm 0,29$ & $5,2 \pm 0,45$ \\
Аланинаминотрансфераза, Ед/л & $89,6 \pm 9,94$ & $71,8 \pm 10,1$ \\
Аспартатаминотрансфераза, Ед/л & $70,2 \pm 12,9$ & $57,5 \pm 7,67$ \\
П р и м е ч а н и е. Состав рационов см. в таблице 3. & \\
\hline
\end{tabular}

Биохимические исследования не выявили существенных изменений в активности пищеварительных ферментов крови и биохимических показателях у поросят при использовании в рационе различных белковых добавок (табл. 8).

Поскольку у птиц и млекопитающих пищеварительные системы морфофункционально различаются, то и биологические механизмы кормовой адаптации у них неодинаковы. Нами впервые в мировой практике предпринято сравнительное изучение особенностей такой адаптации к изменению белкового компонента рациона при замене соевого жмыха (шрота) подсолнечным жмыхом на фистулированных животных.

Результаты исследований показали, что по количеству панкреатического сока за время опыта (в расчете на 1 кг живой массы) куры опережают поросят почти в 2,2 раза. Активность амилазы при использовании в корма 1 у кур составила 4620 253,1 , у поросят $-1564 \pm 267,0$ мг/(мл · мин), что в абсолютных величинах почти в 3 раза ниже, чем у кур. При использовании корма 2 активность амилазы у кур возрастает до 4855 290,0 , а у 


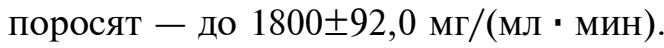

Липолитическая активность панкреатического сока у поросят в абсолютных значениях была выше таковой у кур почти в 2 раза и составила при содержании на контрольном корме соответственно 14,8 $\pm 1,01$ и 6,5 $\pm 0,51$, при замещении белкового компонента (соевый жмых/шрот $\rightarrow$ подсолнечный

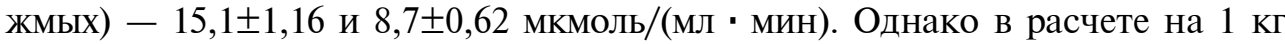
живой массы соотношение липолитической активности у кур и поросят равнялось 17:1.

Гидролиз протеина у кур протекал более интенсивно. Активность протеаз при содержании животных на контрольном корме у кур была в 3 раза

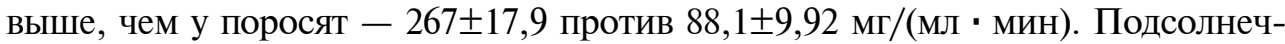
ный шрот повышал активность протеаз у кур до $342 \pm 61,3$ мг/(мл · мин), но снижал у свиней - до 49,6士6,04 мг/(мл · мин). Учитывая, что переваримость сырого протеина при этом существенно не изменяется, можно предположить наличие ингибиторов трипсина в соевом шроте, что усиливает активности протеаз. Это предположение находит подтверждение в работах О.А. Тарасенко (31), который указывает на более высокую доступность аминокислот в подсолнечном шроте (на 25,4 \%) по сравнению с соевым. Наши данные также частично согласуются с результатами сравнительных исследований физико-химических свойств и ферментативной активности панкреатического сока у разных животных (32).

Активность пищеварительных ферментов в плазме крови животных с неодинаковым типом пищеварения существенные различалась по трипсину: в расчете на 1 кг живой массы у кур его активность составила 100, у свиней - 14 ед/л. Следовательно, обменные процессы у кур протекают интенсивнее, чем у свиней, и индекс активности трипсина (активность трипсина/живая масса) может служить критерием оценки активности обмена веществ.

Известно, что обеспечение кормами - самая затратная сфера в экономике животноводства, но здесь же скрыты наибольшие резервы (20). Знание биологических эффектов ингредиентов корма составляет основу формирования сбалансированных рационов для сельскохозяйственных животных. Полученные в настоящей работе данные комплексно характеризуют основные пищеварительные и связанные с питанием обменные процессы. Этот подход дает возможность интерпретировать результаты исследования как в теоретическом, так и в практическом аспекте.

Итак, данные оригинальных экспериментов, выполненных нами на фистулированных животных, позволяют сделать следующие выводы. Отличительная особенность экзокринной функции поджелудочной железы птиц заключается в высокой интенсивности: количество панкреатического сока на единицу живой массы у кур больше, чем у свиней, в 2,2 раза, активность амилазы - в 94 раза, протеаз - в 145 раз, липазы - 17 раз. Индекс активности трипсина в плазме крови кур значительно (в 7 раз) превышает показатель у свиней, что указывает на усиленный обмен веществ. Адаптация панкреатической секреции у кур при замене соевого жмыха подсолнечным характеризуется увеличением активности липазы в панкреатическом соке на 33,8 \%. При этом достоверные различия наблюдаются в базальный и постпрандиальный период через 60 мин после кормления. В результате при использовании подсолнечного жмыха переваримость сырого жира возрастает на 3,5 \%. У свиней при замене соевого шрота подсолнечным жмыхом внешнесекреторная функция поджелудочной железы реагирует снижением протеолитической активности на 43,8 \%. В то же время 
переваримость сырого протеина не изменяется из-за наличия ингибитора трипсина в соевом шроте. У животных независимо от типа пищеварения адаптация панкреатической секреции происходит при непараллельном изменении активности ферментов в ответ на качественные изменения ингредиентов корма.

\section{ЛИТ Е РАТ УРА}

1. Gilliland E.L., Glazer G. Parallel secretion of enzymes by the rabbit pancreas. The Journal of Physiology, 1980, 303(1): 33-41 (doi: 10.1113/jphysiol.1980.sp013268).

2. Фомина Л.С. Секреция поджелудочной железы и ее адаптация к характеру питания. В сб.: Физиология пищеварения /Под ред. А.В. Соловьева. Л., 1974: 360-369.

3. Павлов И.П. Физиология пищеварения. Т. 5, кн. 1. М.-Л., 1952.

4. Rothman S., Leibow C., Isenman L. Conservation of digestive enzymes. Phsyological Reviews, 2002, 82(1): 1-18 (doi: 10.1152/physrev.00022.2001).

5. Ren L.Q., Zhao F., Tan H.Z., Zhao J.T., Zhang J.Z., Zhang H.F. Effects of dietary protein source on the digestive enzyme activities and electrolyte composition in the small intestinal fluid of chickens. Poultry Science, 2012, 91: 1641-1646 (doi: 10.3382/ps.2011-02081).

6. Keomanivong F.E., Grazul-Bilska A.T., Redmer D.A., Bass C.S., Kaminski S.L., Borowicz P.P., Kirsch J.D., Swanson K.C. The impact of diet and arginine supplementation on pancreatic mass, digestive enzyme activity and insulin-containing cell cluster morphology during the estrous cycle in sheep. Domestic Animal Endocrinology, 2017, 59: 23-29 (doi: 10.1016/j.domaniend.2016.10.001).

7. Батоев Ц.Ж. Физиология пищеварения птиц. Улан-Удэ, 2001: 10-63.

8. Фисинин В.И., Вертипрахов В.Г., Грозина А.А., Андрианова Е.Н., Шевяков А.Н., Хасанова Л.В., Аншаков Д.В. Связь между секреторной функцией поджелудочной железы кур и переваримостью корма. Ветеринария и кормление, 2018, 5: 4-7 (doi: 10.30917/ATTVK-1814-9588-2018-5-1).

9. Перепелкина Л.И., Бердников П.П., Самсоненко И.А. Физиологическая адаптация поджелудочной железы мускусных уток к абиотическим для вида составам рациона. Вестник Алтайского государственного аграрного университета, 2012, 7(93): 67-68.

10. Vertiprakhov V.G. Pancreatic exocrine function in hens with addition of lysine and methionine to their ration. Russian Agricultural Sciences, 2015, 41(2-3): 171-174 (doi: 10.3103/S1068367415020275).

11. Фисинин В.И., Вертипрахов В.Г., Грозина А.А., Хасанова Л.В. Панкреатическая секреция и усвоение аминокислот в кишечнике кур при разных источниках белка в рационе. Сельскохозяйственная биология, 2017, 52(2): 374-381 (doi: 10.15389/agrobiology.2017.2.374rus).

12. Коротько Г.Ф. Секреция поджелудочной железы: от Павловских начал к настоящему. Российский журнал гастроэнтерологии, гепатологии, колопроктологии, 2014, 3: 4-12.

13. Rothman S., Liebow C., Grendell J. Nonparallel transport and mechanisms of secretion. Biochimica et Biophysica Acta, 1991, 1071(2): 159-173 (doi: 10.1016/0304-4157(91)90023-P).

14. Можейко Л.А. Морфофизиологическое обоснование непараллельной экзокринной секреции ферментов поджелудочной железы. Новости медико-биологических наук, 2017, 15(1): 72-76.

15. Brannon PM. Adaptation of the exocrine pancreas to diet. Annual Review of Nutrition, 1990, 10: 85-105 (doi: 10.1146/annurev.nu.10.070190.000505).

16. Swanson K.C., Matthews J.C., Woods C.A., Harmon D.L. Postruminal administration of partially hydrolyzed starch and casein influences pancreatic $\alpha$-amylase expression in calves. The Journal of Nutrition, 2002, 132(3): 376-381 (doi: 10.1093/jn/132.3.376).

17. Sans M.D., Williams J.A. Translational control of protein synthesis in pancreatic acinar cells. Int. J. Gastrointest. Cancer, 2002, 31(1-3): 107-115 (doi: 10.1385/IJGC:31:1-3:107).

18. Huguet A., Savary G., Bobillier E., Lebreton Y., Le Huërou-Luron I. Effects of level of feed intake on pancreatic exocrine secretions during the early postweaning period in piglets. Journal of Animal Science, 2006, 84(11): 2965-2972 (doi: 10.2527/jas.2006-044).

19. Liu K., Shen J., Cao Y., Cai C., Yao J. Duodenal infusions of isoleucine influence pancreatic exocrine function in dairy heifers. Archives of Animal Nutrition, 2018, 72(1): 31-41 (doi: 10.1080/1745039X.2017.1396144).

20. Синещеков А.Д. Биология питания сельскохозяйственных животных. М., 1965.

21. Ткачев И.З. Комплексное (физиологическое и зоотехническое) изучение процессов питания у свиней. М., 1988: 25-26.

22. Вертипрахов В.Г., Грозина А.А. Оценка состояния поджелудочной железы методом определения активности трипсина в крови птицы. Ветеринария, 2018, 12: 51-54 (doi: 
10.30896/0042-4846.2018.21.12.51-54).

23. Андрианова Е.Н., Егоров И.А., Присяжная Л.М., Григорьева Е.Н., Ребракова Т.М. Нужно ли учитывать содержание хлорогеновой кислоты в подсолнечнике при оценке качества продуктов его переработки? Птица и птицепродукты, 2016, 2: 39-41.

24. Kudo K., Nishimura S., Tabata S. Distribution of taste buds in layer-type chickens: scanning electron microscopic observations. Animal Science Journal, 2008, 79(6): 680-685 (doi: 10.1111/j.1740-0929.2008.00580.x).

25. Kudo K., Shiraishi J., Nishimura S., Bungo T., Tabata S. The number of taste buds is related to bitter taste sensitivity in layer and broiler chickens. Animal Science Journal, 2010, 81(2): 240-244 (doi: 10.1111/j. 1740-0929.2009.00729.x).

26. Wang Z., Yoshida Y., Kramer N.E., Kawabata F., Tabata S., Woo K. Kim W.K., Liu H.-X. Abundant proliferating cells within early chicken taste buds indicate a potentially "built-in" progenitor system for taste bud growth during maturation in hatchlings. Histology and histopathology, 2019, 34(5): 503-511 (doi: 10.14670/HH-18-055).

27. Chey W.Y. Regulation of pancreatic exocrine secretion. Int. J. Pancreatol., 1991, 9(1): 7-20 (doi: 10.1007/BF02925574).

28. Фисинин В.И., Вертипрахов В.Г., Грозина А.А. Внешнесекреторная функция поджелудочной железы кур (Gallus gallus L.) в зависимости от ингредиентов рациона. Сельскохозяйственная биология, 2018, 53(4): 811-819 (doi: 10.15389/agrobiology.2018.4.811rus).

29. Pangeni D., Jendza J.A., Meno D.R., Anil L., Yang X., Baidoo S.K. Effect of replacing conventional soybean meal with low oligosaccharide soybean meal fed to weanling piglets. Journal of Animal Science, 2016, 95(1): 320-326 (doi: 10.2527/jas.2016.0780).

30. Mentzel C.M.J., Cardoso T.F., Lex A.M.J., Sørensen D.B., Fredholm M., Cirera S. Fat and carbohydrate content in the diet induces drastic changes in gene expression in young Guttingen minipigs. Mamm. Genome, 2017, 28: 166-175 (doi: 10.1007/s00335-017-9690-y).

31. Тарасенко О.А., Омаров М.О., Головко Е.Н., Каширина М.В. Доступность аминокислот в белковых кормах. Животноводство России, 2007, 10: 27-28.

32. Смолин С.Г. Физико-химические показатели и активность ферментов сока поджелудочной железы у кур, свиней и собак: монография. Красноярск, 2008.

\author{
${ }_{1}^{1}$ ФНЦ Всероссийский научно-исследовательский \\ и технологический институт птицеводства РАН, \\ 141311 Россия, Московская обл., г. Сергиев Посад, \\ ул. Птицеградская, 10, \\ e-mail: Vertiprakhov63@mail.ru $₫$, olga@vnitip.ru, Alena_fisinina@mail.ru; \\ 2ФГБНУ Всероссийский НИИ физиологии, биохимии \\ и питания животных - филиал ФГБНУ ФНЦ \\ животноводства - ВИЖ им. академика Л.К. Эрнста, \\ 249013 Россия, Калужская обл., г. Боровск, пос. Институт, \\ e-mail: evgenijkharito@yandex.ru
}

Sel'skokhozyaistvennaya biologiya [Agricultural Biology], 2019, V. 54, № 6, pp. 1122-1134

\title{
THE ADAPTATION OF PANCREATIC SECRETION AND METABOLISM IN ANIMALS WITH DIFFERENT DIGESTION TYPE TO CHANGES IN DIETARY PROTEIN INGREDIENTS
}

\section{V.I. Fisinin', V.G. Vertiprakhov', E.L. Kharitonov' ${ }^{2}$, A.A. Grozina ${ }^{1}$}

\begin{abstract}
${ }^{1}$ Federal Scientific Center All-Russian Research and Technological Poultry Institute RAS, 10, ul. Ptitsegradskaya, Sergiev Posad, Moscow Province, 141311 Russia, e-mail Vertiprakhov63@mail.ru ( $\square$ corresponding author), olga@vnitip.ru, Alena_fisinina@mail.ru;

${ }_{2}^{2}$ All-Russian Research Institute of Animal Physiology, Biochemistry and Nutrition - Branch of Ernst Federal Science Center for Animal Husbandry, Federal Agency of Scientific Organizations, pos. Institut, Borovsk, 249013 Russia, e-mail evgenijkharito@yandex.ru
\end{abstract}

ORCID:

Fisinin V.I. orcid.org/0000-0003-0081-6336

Vertiprakhov V.G. orcid.org/0000-0002-3240-7636

Kharitonov E.L. orcid.org/0000-0001-9654-7710

The authors declare no conflict of interests

Grozina A.A. orcid.org/0000-0001-9654-7710

Acknowledgements:

Supported financially by the Program of Basic Scientific Research of the Russian Academy of Sciences, subprogram "Studying the mechanisms of adaptation of the digestive system of mammalian animals and poultry to rations with different ingredient composition of feed" (Decree of the Presidium RAS No. 132 of July 5, 2017)

Received September 19, 2019

doi: 10.15389/agrobiology.2019.6.1122eng 


\begin{abstract}
The adaptation of the pancreas to diet composition is still a matter of discussion. The methodical difficulties related to the sampling of pure pancreatic juice resulted in the scarce and discrepant published data on the alterations of exocrine pancreatic secretion in response to changes in diet composition (A.D. Sineshchekov, 1965; P.P. Berdnikov, 1990; Ts.Zh. Batoev, 2001; A. Huget et al., 2006; V.I. Fisinin et al., 2017; K. Liu et al., 2018); the effects of individual dietary ingredients on the pancreatic secretion were not scrutinized to date. We present a comparative study on the alterations of exocrine pancreatic function in response to the change in dietary protein source (substitution of sunflower cake for soybean cake or meal) with the use of similar methodology for animals with different digestion type; this approach can reveal both specific and common patterns in the respective adaptive reactions. The study was performed on 18 laying hens (Gallus gallus domesticus L.; cross Hisex White) at 10-12 months of age including 3 hens with chronic fistulae of main pancreatic duct inserted according to the method of Ts.Zh. Batoev (2001), and on 9 piglets (Sus scrofa domesticus L.; hybrid of Danish Landrace and Danish Yorkshire breeds) at 5 months of age and $45-55 \mathrm{~kg}$ of live bodyweight including 3 intact piglets, 3 piglets with cannulated pancreatic duct, and 3 piglets with ileal cannulae. It was found that the most responsive enzymatic activity in chicken is lipase: in hens fed diet with sunflower cake the basal (preprandial) level of lipase activity was significantly higher by $37.7 \%$ in compare to diet with soybean meal, postprandial lipase activity in $90 \mathrm{~min}$ after feeding higher by $46.6 \%$; in $150 \mathrm{~min}$ after feeding higher by $93.7 \%(\mathrm{p}<0.05)$. The shift from soybean meal to sunflower cake resulted in the significant increase in crude fat digestibility by $3.5 \%(\mathrm{p}<0.05)$. This shift was also found to increase the postprandial protease activity though similar response of crude protein digestibility was not found. To the contrary, the same shift in diet composition in pigs resulted in the significant decrease in postprandial protease activity by $43.8 \%(\mathrm{p}<0.05)$; no alterations were found in the digestibility of crude protein probably due to the presence of trypsin inhibitor(s) in soybean meal. Regardless of the similar total volumes of pancreatic juice secreted in pigs during the sampling period with different dietary protein sources the dynamics of the postprandial pancreatic secretion substantially differed with these sources both in the complex-reflex and neurohumoral regulative phases. The exocrine pancreatic function in chicken was considerably more strenuous in compare to pigs: the relative (per $1 \mathrm{~kg}$ of live bodyweight) volume of pancreatic juice secreted in chicken was 2.2 -fold higher, total amylase activity secreted was 94 -fold higher, protease activity 145 -fold higher, lipase activity 17 -fold higher in compare to pigs. The tryptic activity in blood serum in chicken was 7 -fold higher in compare to pigs evidencing higher metabolic intensity. Therefore, when changing the dietary ingredients the functional peculiarities of the adaptation of pancreatic secretion to these shifts in the productive animals with different digestion type should be taken into account since exocrine pancreatic function and feed digestibility are correlated and can, in turn, jointly affect the productive performance.
\end{abstract}

Keywords: pancreas, exocrine pancreatic function, chicken, pigs, activities of digestive enzymes in blood serum. 